the addition of two or three scientific and technical men to this committee is necessary. So far as we can see, none of the committee has any real knowledge of the scientific principles underlying the problems its members will have to discuss. We hope that this will soon be remedied. It is necessary to consider the instructional and entertainment values of broadcasting, but it would be foolish to neglect the scientific development of the art. We have tried to find out from the Annual the amount expended in 1934 on research. Unfortunately this does not appear ; it is apparently included in the general sum of $£ 334,959$ mentioned on p. 91 for maintenance, salaries, development and research, etc.

\section{Science and Social Responsibility}

IN the April number of State Service, the journal of the Institution of Professional Civil Servants, Prof. H. Levy contributes an interesting article on this topic. The social consequences, he says, that have flowed in the wake of technical advance stand now in such clear outline that even scientific men, traditionally concerned only with the internal content of their work and not with its external repercussions, are beginning to lose their complacency. In the past, the scientific method excluded from its scope all matters involving prejudice, desire, bias or purpose, and was purely objective in character. In the logic of the physical sciences, human desires play no part, but in the social sciences they are fundamental. The pursuit of science is essentially a co-operative activity and is therefore socially conditioned. It is directed to an end, and that end is its social purpose, but since the direction which scientific investigation takes is in this way socially determined, science itself becomes one of the determining factors of society. It improves the technical level of production; it introduces new factors into the way of living for the population; it affects their cultural interests; it creates new needs and therefore arouses new hopes and desires. In almost every walk of life, laws of detailed social behaviour on which action is based are already recognised. Is it too much to suggest that here in small detail are the kinds of regularities and recurrences that make a science possible? Are we not therefore entitled to expect corresponding regularities, perhaps deeper and more far-reaching, on a large scale, and as a consequence, since society is dynamic, a logic of social change ? Since science is itself a motivating factor in that change, its study is a scientific responsibility.

\section{British Trust for Ornithology}

FIELD ornithologists in the British Isles are making an experiment in co-operative research which, if successful, may have far-reaching implications. They have a peculiar problem to deal with, partly because the great majority of them are not trained men of science, and yet are being led on to territory where an advanced scientific technique is essential. Some of the combined operations recently carried out have been on an impressive scale. The census of heronries in 1928 needed some five hundred observers before it was completed, while the great crested grebe inquiry of 1931 and the two-year woodcock inquiry now in progress have each enlisted more than a thousand observers. Naturally such work calls for a high degree of organisation, but until very recently British field ornithologists as such possessed no national organisation whatever. Irreplaceable manuscripts, field-notes, photographs, maps and collections of literature or bibliography were got together and dispersed according to the hazards of individual existence. A number of prominent ornithologists, including Mr. H. F. Witherby, president of the British Ornithologists' Union and editor of British Birds, Prof. Julian Huxley, the Rev. F. C. R. Jourdain, secretary of last year's International Ornithological Congress, and Dr. P. R. Lowe of the British Museum, combined to fill this gap by forming the British Trust for Ornithology as a permanent national trustee for the interests of field ornithologists. The Trust itself holds capital funds and assets in kind, such as a library, and collects subscriptions, which enable it to make grants for ornithological research. These grants, which at present are only on a very small scale, are being used to develop the nucleus of an Institute of Field Ornithology at Oxford, recognised and administered by the University. A national planning committee for the ornithological programme as a whole has been set up jointly by the Trust and the University.

ThE Trust's first report just issued shows that, in spite of very cramped finances, a wide range of research has already been undertaken with marked success. Special reference should be made to the enterprise of the Trust in starting an experimental annual index of heron numbers, based on a twentyfive per cent sample of the breeding heron population of England and Wales. The index for 1934 is given as 102, 1928 being taken as 100. Another interesting point is the linking up of census work on swallows with a study of the size of broods, association with domestic animals at breeding places and occurrence of certain lethal parasites. The inquiries into shorteared owl habits during a vole plague on a Forestry Commission estate, and into the effect of the recent drought on great crested grebes, are further examples of the broad range of research which this comprehensive and flexible type of organisation makes possible. The Trust is still in an experimental stage. Inquiries and offers of help should be addressed to the Honorary Secretary, Mr. E. M. Nicholson, 61 Marsham Street, London, S.W.1.

\section{Earthquakes in Persia}

Destructive earthquakes have recently visited the Persian province of Mazanderan that lies along the southern border of the Caspian Sea. The first shock occurred on April 12, and was followed by others of greater severity during the next few days. It is stated (The Times, April 24 and 27) that 28 villages have been destroyed and about 600 persons killed. The province is one that is seldom disturbed by great earthquakes, though it lies near the important centres of Teheran and Resht. Sir Arnold Wilson, in his valuable paper on earthquakes in 
Persia (Bull. Sch. Oriental Studies, 6, 103-131; 1930), records two earthquakes in Mazanderan, in 1802 and 1820, that have hitherto escaped the attention of seismologists. By the earlier shock, 70 towns and villages were destroyed, while the towns of Semnan and Damghan, to the south of the province, were seriously damaged.

\section{Rockefeller Medical Fellowships}

THE Rockefeller Medical Fellowships for the academic year 1935-36 will shortly be awarded by the Medical Research Council, and applications should be lodged with the Council not later than June 1, 1935. These Fellowships are provided from a fund with which the Medical Research Council has been entrusted by the Rockefeller Foundation. Fellowships are awarded by the Council, in accordance with the desire of the Foundation, to graduates who have had some training in research work in the primary sciences of medicine, or in clinical medicine or surgery, and are likely to profit by a period of work at a university or other chosen centre in the United States or on the Continent of Europe, before taking up positions for higher teaching or research in the British Isles. A Fellowship held in America will have the value of not less than $£ 350$ a year. Full particulars and forms of application are obtainable from the Secretary, Medical Research Council, 38 Old Queen Street, Westminster, S.W.1.

\section{Announcements}

His Majesty the King has conferred his patronage on the fifty-fourth annual meeting and conference of the Society of Chemical Industry to be held in Glasgow on July 1-6. Among the subjects to be discussed are the transport of food by road, rail and sea, problems of water supply, and chemical engineering in the Navy.

WE regret to announce the death, on April 27 at the age of seventy-three years, of Prof. H. B. Baker, F.R.S., lately professor of general chemistry in the Imperial College of Science and Technology.

Dr. George Sarton, editor of Isis, the quarterly organ of the History of Science Society and of the International Academy of the History of Science (Harvard Library, 185, Cambridge, Mass., U.S.A.), has been elected a corresponding member of the Academia de la Historia of Madrid.

ThE Ramsay Memorial Fellowships Trustees will consider at the end of June applications for a Ramsay Memorial Fellowship for chemical research, of the value of $£ 250$ a year. Particulars of the award can be obtained from the Secretary of the Ramsay Memorial Fellowships Trust, University College, London (Gower Street, W.C.1).

The Linacre Lecture at St. John's College, Cambridge, will be delivered by Mr. P. P. Laidlaw, pathologist to the Medical Research Council, National Institute for Medical Research, on Tuesday, May 7, at 5 p.m. in the new lecture-room of physiology. The title of the lecture will be "Epidemic Influenza: A Virus Disease".
A COURSE of eight lectures on pathological research in its relation to medicine is being given on Thursdays, commencing May 2, at the Institute of Pathology and Research, St. Mary's Hospital, W.2. The lecturers are Sir Almroth Wright, Prof. E. D. Adrian (electrical activity of the brain), Dr. I. N. Asheshov (bacteriophage), Dr. C. H. Andrewes (cancer), Dr. R. G. Canti (cultivation of living tissue), Sir Henry Dale (active substances of ergot), Mr. J. Henderson Smith (virus diseases of plants and animals) and Dr. J. Needham (chemical embryology). The lectures are open to members of the medical profession and medical students, without fee.

The seventh Natural Science Congress of the Dutch Indies will be held at Batavia on October 23-26. The agenda will include addresses by Prof. R. Remmelts and Dr. L. J. C. Van Es as well as meetings of sections. Further information can be obtained from the Secretariat, Koningsplein Z11, Batavia.

A SPECIAL exhibition of welding has been arranged at the Science Museum, South Kensington, and will remain on view until May 15. The exhibits include a wide range of machines used in welding by the oxy-acetylene, resistance, atomic hydrogen and arc processes, and a representative selection of examples of welded work. Demonstrations of the first three processes are being given daily at $11-1$ and 3-5, and films illustrative of welding are being shown every afternoon in the Lecture Theatre at 4 . The exhibition is supplementary to the symposium on welding on May 2-3 organised by the Iron and Steel Institute in co-operation with a number of other technical societies and institutions.

Applications are invited for the following appoint. ments, on or before the dates mentioned :-An assistant (II) for research in aero engines and accessories at the Royal Aircraft Establishment, South Farnborough, Hants-The Chief Superintendent (May 7). A laboratory research assistant in the Glamorgan County Mental Hospital, Bridgend-The Medical Superintendent (May 15). An assistant (Grade III) for abstracting scientific and technical papers in the Department of Scientific and Industrial Research-The Establishment Officer, 16 Old Queen Street, Westminster, S.W.1 (May 15). A head of the Mechanical Engineering Department, Central Polytechnic, Croydon-The Education Officer, Education Office, Katharine Street, Croydon (May 15). An inspector of agriculture in the Department of Agriculture and Forests, Sudan Government-The Controller, Sudan Government London Office, Wellington House, Buckingham Gate, London, S.W.1 (June 10). A lecturer in mathematics in Huddersfield Technical College-The Director of Education, Education Offices, Peel Street, Huddersfield. A principal of the Swansea Technical College-The Director of Fiducation, Swansea. An assistant for soil survey work at Harper Adams Agricultural College, Newport, Shropshire-The Principal. A lecturer in geography in Armstrong College, Newcastle-upon-Tyne-The Registrar. 